\title{
A DECISION MAKING MODEL TO SELECT THE TECHNOLOGY IN AN ENTERPRISE
}

\section{DECYZYJNY MODEL WYBORU TECHNOLOGII W PRZEDSIECIORSTWIE}

\author{
Grzegorz Hoppe \\ Remondis Ltd. Bydgoszez \\ Remondis Bydgoszcz sp. z o.0. ul.Inwalidów 4, 85-749 Bydgoszcz \\ e-mail: grzegorz.hoppe@op.pl
}

\begin{abstract}
Each enterprise employs the technologies to make its products which are being continuously adapted to meet the needs of the changing market. The changes to the environment states affect particularly the decisions regarding selection or change of these technologies. There are significant elements in the environment having crucial influence on this decision choosing process. Therefore, creating a decision making model to select the technology in an enterprise depending on the changes of the environment element states may be a tool to support the decision making process.
\end{abstract}

Keywords: enterprise, environment, technology, decision making process model

Streszczenie. Każde przedsiębiorstwo stosuje technologie wytwarzania swoich produktów, które w sposób ciagły są dostosowywane do potrzeb zmieniającego się rynku. Szczególnie zmiany stanów otoczenia mają wpływ na decyzje dotyczące wyboru lub zmiany tych technologii. W otoczeniu istnieją elementy istotne, których wpływ na ten wybór jest decydujący. $Z$ tego powodu budowa decyzyjnego modelu wyboru technologii $\mathrm{w}$ przedsiębiorstwie zależnego od zmian stanów elementów otoczenia może stanowić narzędzie wspomagające proces decyzyjny.

Slowa kluczowe: przedsiębiorstwo, otoczenie, technologia, model procesu decyzyjnego 


\section{Introduction}

The object of the study is a system combined of two subsystems: an enterprise and its environment. The changing states of the environment elements affect the enterprise state changes, thus requiring changes of its operation method.

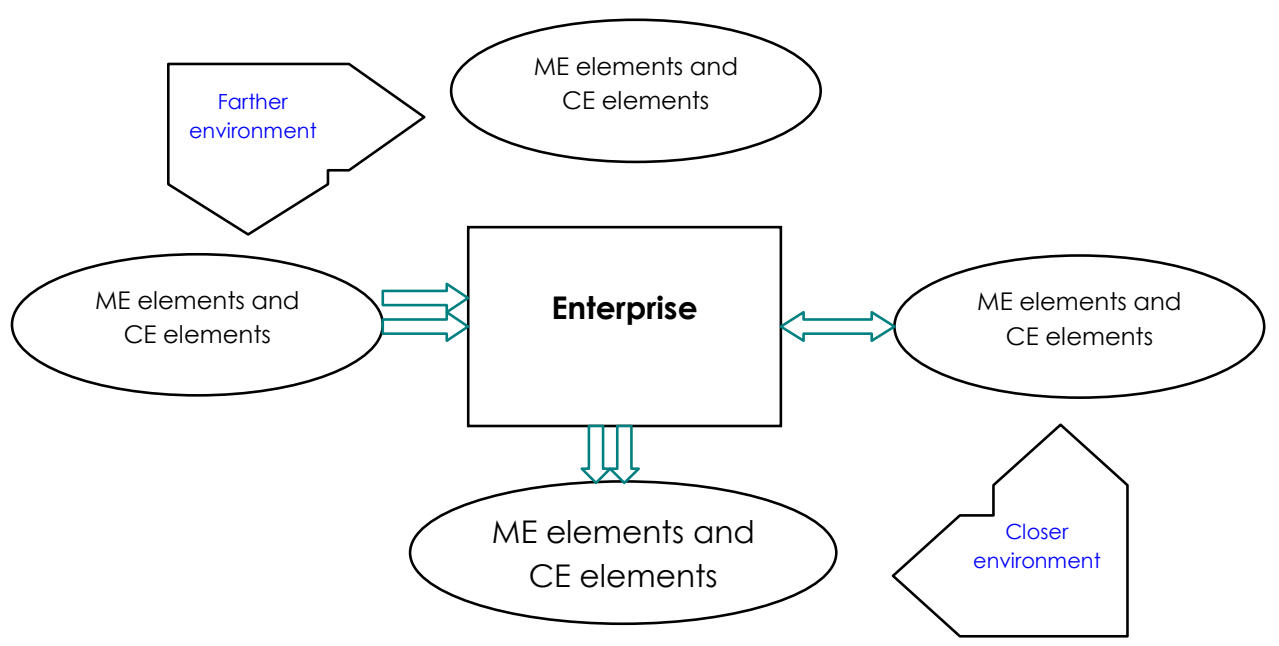

Fig. 1. Enterprise environment (ME- macro-environment, $\mathrm{CE}$ - competitive environment).

The enterprise environment is defined by the description of its components and its structure. The set of the environment components is usually divided into elements belonging to the macro-environment and to the competitive environment. Because of the interactions between the environment and the enterprise, closer environment and farther environment are distinguished in the set of the components. Such a division is presented in the figure 1, including the interaction directions resulting from the classification adopted. The closer environment is made of those macro-environment elements (ME) and the competitive environment elements (CE) which are influenced by the enterprise. The farther environment includes those elements of the macro-environment and the competitive environment which affect or do not affect the enterprise and which are not influenced by the enterprise actions. It has been assumed that the macro-environment is represented by: economic, culture, social, political, legal, technological, physical and international factors. The aforementioned factors are characterised as follows: 
- economic - general economic conditions affecting an organisation performance. Its essential elements are for instance: unemployment, inflation, model of economy, fiscal policy, access to raw materials and their price level, economic situation and banking system.

- culture - history, tradition or system of values generally accepted within a specific society.

- social - consisting of demographic dependences, lifestyle patterns, mobility of the society, social institutions. This factor includes such components as: religious preferences, demographic growth, ageing of the society or its migrations.

- political - it is mainly current political system and its stability as well as the rules and extent of the state interventionism.

- legal - it is the legal system in force, and in particular, the legislation related to the economic activities.

- technological - it is the present state of knowledge and access to the contemporary technologies which may be employed and used in the process to make products and to provide services.

- physical - influence of the natural environment in which the enterprise exists including its all constraints and threats such as natural disasters.

- international - representing influences of the international institutions and global trends.

It should be added that all the macro-environmental factors may interact not only with the enterprises, but also with one another.

Another element of the enterprise environment is its competitive environment which can be divided into the following elements:

clients, existing and potential competitors, suppliers, owners (shareholders), authorities, pressure groups, trade unions.

There are or there may be interactions between all those elements, at the same time each of the elements of a specific enterprise may be or it is an element of other enterprises. Using the conception of a system we may state that we face here a complex system being the global economy with the global environment in which a great number of subsystems are embodied, the smallest one of which is the enterprise under consideration including its environment. 


\section{Relations between an enterprise and its environment}

An enterprise as an open system is affected by the environment elements through its input factors that means through the resources and its output factors that means its products and services. Because each resource is limited, and the output factors can be accepted by the environment in limited number, the system is a dependable one. This situation is shown in the figure 2 .

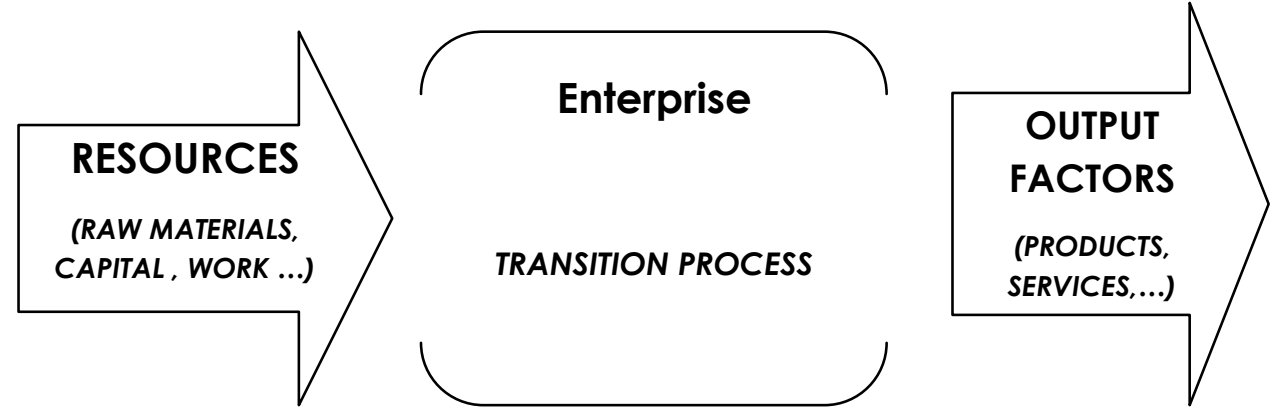

Fig. 2. Enterprise as an open system depending on its environment.

It unambiguously means that the enterprise is "ruled" by the enterprise, and the enterprise may only look for a strategy, the realisation of which will minimise that dependence. It is important to identify those resources which are crucial for the enterprise performance, and to investigate thoroughly the raw material shortfalls in its environment.

Another step is to look for possibility to make the environment depend on the enterprise output factors and to protect the enterprise against the raw material shortfalls by, for instance, signing relevant contracts.

Because each enterprise affects other enterprises, one should try to make the enterprise output factors become significant resources for the others and try to influence one's own environment to convert it into the resources for the shortfalls. An example here may be production of highly specialized semiproducts which, on one hand, are looked for by the market, and on the other hand, their production process requires high investment expenditures. Another example is extraction of the mineral raw materials which are 
important for the market and the resources of which are significantly limited, or their extraction is a complex technological process.

In the theory of the management sciences one may also find other presentations of the relations between the environment and an enterprise.

In the institutional theory two major aspects are required from an enterprise: requirements of the technology-and-economy as well as the requirements of the society, it means that the environment makes the enterprise use adequate technologies or play a specific social role. The conception of the social legitimisation as another input resource is also described in the references, it means that an enterprise depends on the social acceptance. All these theories consent that an enterprise depends on its environment. The only differences between them are the perspective from which those relations are judged (analysed) or the distinguishing some factors as more important ones or the introduction of new factors. Another important difference is determination of the influence of an enterprise on the environment. Only in the first of the presented theories, meaning the dependence on the resources, an enterprise is perceived as an active participant being able to change the environment, while it entirely depends on the environment in the remaining ones.

\section{Influence of the environment on the decision making process to select the technology}

Because the environment has influence on the processes taking place in an enterprise, it has also influence on the decisions regarding selection of the technologies to be used. The technology should be understood as the major technological processes in an enterprise to make products and provide services as well as the processes to convert raw materials. It is important to determine which interactions of the environment elements are significant ones, being crucial for the technology selection process, thus enabling selection of the strategy being the most favourable for the enterprise.

Different interactions of the environment elements are significant for the technological processes in each sector. An important role in selecting an optimal technological process is also played by the size of the enterprise, its geographical location, access to the raw materials, strength of the competition. 


\section{Model of the decision making process to select the technology in an enterprise, within changing conditions of the environmental influence}

In the environment being changeable in time, the selection of the technology depends on the successive states of its individual elements. A model of decision making process to select the technology depending on the changes of the enterprise environment is presented hereunder.

The decision making process model is understood as the ordered three described as:

$$
\left\langle E, A, Z_{E A}\right\rangle
$$

where:

$\mathbf{E}$ is a finite set of the environmental element states; for each moment $t \in T$ the environmental element state is the vector $e_{t}=\left\langle e_{1}^{t}, \ldots, e_{n}^{t}\right\rangle$; where $e_{k}^{t}$ stands fro the $k$-th environmental element at the moment $t$.

$\mathbf{A}$ is a finite set of the actions that can be applied for the enterprise at the moment it is in a specific environmental state at the determined time moment; for each state $e_{t} \in E, t \in T$ the following action may be applied $a_{t}=\left\langle a_{1}^{t}, \ldots, a_{n}^{t}\right\rangle$, at the same time it is assumed that $a_{k}^{t}$ is a value of the set $\{0,1\}$. The value of zero means no influence of the $k$-the environmental element on the enterprise performance, and the value of one means that such an influence exists.

$\mathbf{Z}_{\mathbf{E A}}$ is a set of the income function, formulated as

$z_{e_{t}}^{a_{t}}: T \rightarrow R$

being realised at the time the enterprise sojourns in the state $e_{t} \in E$ when applying the action $a_{t} \in A$. The functions of the set $\mathrm{Z}_{\mathrm{EA}}$ are assumed to be continues and limited ones.

The described model is a stochastic, changeable and continuous in time as well as discrete in the state. It means that it includes at least some of the descriptive variables being random variables, that the events may occur at any moment $\mathrm{t} \geq 0$, and not as multiplication of a determined time unit, and that the system state set is no more than countable (actually it will be finite in each specific application). 
A decision making process is understood as a model with such a property that at the moment it occurs in an enterprise in the specific environment state, various action may be applied having influence on the costs and incomes of the enterprise.

The realisation of the decision making process in the model for a single enterprise, is the sequence (3):

$e_{0}, a_{0}, e_{1}, a_{1}, e_{2}, a_{2}, \ldots$

where $e_{j}$ describes the state of the environmental elements, in which an enterprise is, while $a_{j}$ stands for the undertaken action regarding the enterprise.

If the moments, at which the state changes occur are denoted with the symbols $t_{0}, t_{1}, \ldots$, and the state sojourn times with the symbols $\tau_{0}, \tau_{1}, \ldots$, then there is the following relation (4):

$\tau_{k}=t_{k+1}-t_{k}$

At the time the enterprise is in the state $e_{t_{k}} \in E$ from the moment $t_{k}$ to the moment $t_{k+1}$ and assuming that the action $a_{t_{k}} \in A$ was applied for this object, then the generated incomes may be described with the function $z_{e_{t_{k}}}^{a_{t_{k}}}(t)$. The incomes gained in the time $\tau_{k}$ that means from the moment $t_{k}$ to the moment $t_{k+1}$ may be described with the relation (5):

$$
W_{i}^{t_{k}}\left(\tau_{k}\right)=\int_{t_{k}}^{t_{k+1}} z_{e_{t_{k}}}^{a_{t_{k}}}(t) d t
$$

The average value (per time unit) of the income gained in time from the moment $t_{k}$ to the moment $t_{k+1}$ is then (6):

$$
\frac{W_{i}^{t_{k}}\left(\tau_{k}\right)}{\tau_{k}}=\frac{1}{\tau_{k}} \int_{t_{k}}^{t_{k+1}} z_{e_{t k}}^{a_{t_{k}}}(t) d t
$$


The total income value within the period of the successive $n$ of the state changes (being equal to the area limited by the income function graphs) is expressed with the relation (7):

$$
D\left(t_{0}, t_{n}\right)=\sum_{k=0}^{n} \int_{t_{k}}^{t_{k+1}} z_{e_{t_{k}}}^{a_{t_{k}}}(t) d t
$$

where $e_{t_{k}}$ stands for the environment state, in which the enterprise is at the moment $t_{k}$, and $a_{t_{k}}$ is the action applied at the moment the system entered the state $e_{t_{k}}$.

\section{Summary}

The model described hereabove may be implemented to optimise decision making processes to select the technology in the processing enterprises. In real conditions it is needed to determine, for the selected sector, interactions of the environment elements, being important for the selection of the technology in the respective sector. Identification of the changes of the environment element states may be helpful to give prognosis for their future states. It is extremely important, because the decisions regarding selection of the technologies should be taken on the basis of the prognosis, is such a way to be ahead of the competitors' decisions, taking into consideration the prospect needs of the market.

\section{References:}

1. Butra J., Jankowski A., Kicki J., Siewierski S., Wanielista K., Enterprise $i$ jego environment $w$ gospodarce rynkowej, WIGSMiE PAN, Kraków 1999

2. Gierszewska G., Romanowska M., Analiza strategiczna enterprise, PWE, Warszawa 2003

3. Hatch M. J., Teoria organizacji, PWN, Warszawa 2002

4. Lisiński M., Metody planowania strategicznego, PWE, Warszawa 2004

5. Neubauer A., Symulacyjna metoda optymalizacji procesu eksploatacji realizowanego w systemie transportowym (praca doktorska) 2005

6. Obłój K., Strategia organizacji - w poszukiwaniu trwałej przewagi konkurencyjnej, PWE, Warszawa 2007 
7. Porter M. E., Przewaga konkurencyjna - osiaganie i utrzymywanie lepszych wyników, Helion, Gliwice 2006

8. Porter M. E., Strategia konkurencji - metody analizy sektorów $i$ konkurentów, MT Biznes, Warszawa 2006

9. Woropay M., Knopik L., Landowski B., Modelowanie procesów eksploatacji $w$ systemie transportowym, Instytut Technologii Eksploatacji, Bydgoszcz-Radom 2001

10. Woropay M., Podstawy racjonalnej eksploatacji maszyn. Biblioteka problemów Eksploatacji, Instytut Technologii Eksploatacji, Radom 1996

11. Woropay M., Landowski B., Neubauer A., Wykorzystanie decyzyjnych procesów semi-Markowa do modelowania i symulacji procesu eksploatacji autobusów. Wydawnictwo Naukowe PTNM, Archiwum Motoryzacji Vol. 7, Nr 1, 2004 


\section{DECYZYJNY MODEL WYBORU TECHNOLOGII W PRZEDSIĘBIORSTWIE}

\section{Wstęp}

Obiektem badań jest system złożony $\mathrm{z}$ dwóch podsystemów: przedsiębiorstwa i jego otoczenia. Zmieniające się stany elementów otoczenia wpływaja na zmiany stanów przedsiębiorstwa powodując konieczność zmian sposobu jego działania.

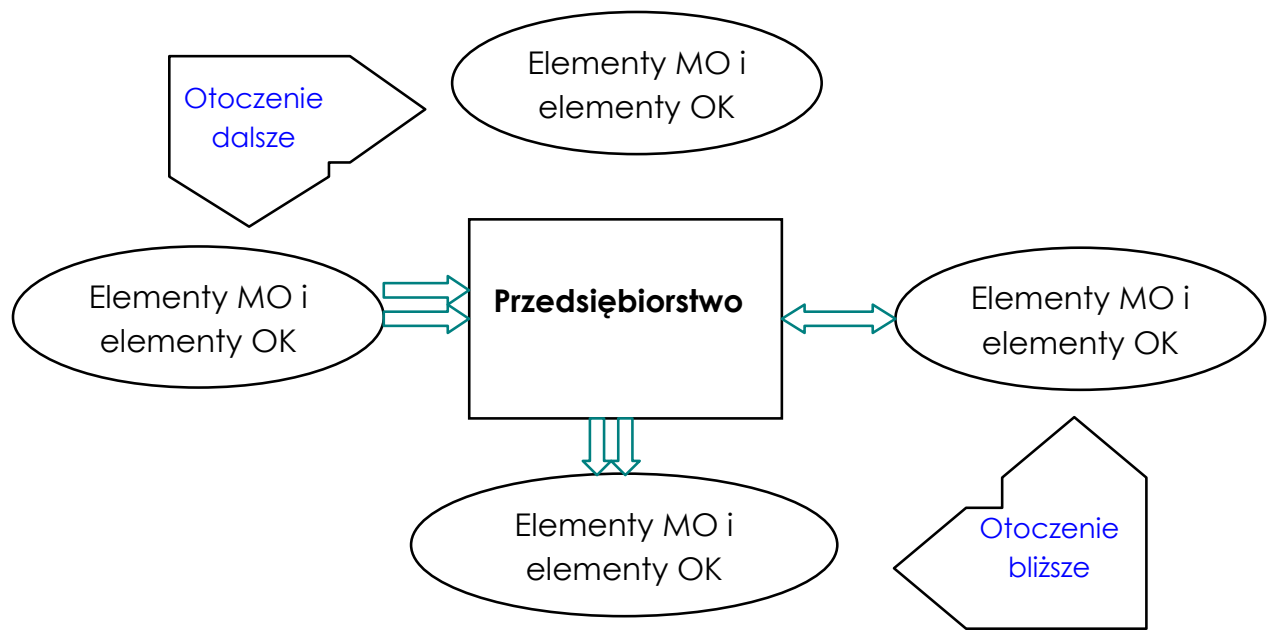

Rys. 1. Otoczenie przedsiębiorstwa (MO- makrootoczenie, OK- otoczenie konkurencyjne).

Otoczenie przedsiębiorstwa definiuje się poprzez opis jego elementów składowych oraz jego struktury. Zbiór elementów składowych otoczenia dzieli się zwykle na elementy należące do makrootoczenia i otoczenia konkurencyjnego. Ze względu na interakcje otoczenia z przedsiębiorstwem $\mathrm{w}$ zbiorze elementów otoczenia wyróżnia się na otoczenie bliższe i otoczenie dalsze. Ten podział przedstawiono na rysunku $1, \quad \mathrm{z}$ uwzględnieniem kierunków oddziaływań wynikających $\mathrm{z}$ przyjętej klasyfikacji.

Otoczenie bliższe to te elementy makrootoczenia (MO) i elementy otoczenia konkurencyjnego (OK), na które przedsiębiorstwo oddziałuje. Otoczenie dalsze zawiera elementy makrootoczenia i otoczenia 
konkurencyjnego, które oddziałują na przedsiębiorstwo lub nie i które nie są pod wpływem oddziaływania przedsiębiorstwa.

Przyjęto, że makrootoczenie reprezentują następujące czynniki: ekonomiczny, kulturowy, społeczny, polityczny, prawny, technologiczny, fizyczny i międzynarodowy. Charakterystyka wymienionych czynników jest następująca:

- ekonomiczny - ogólne warunki ekonomiczne mające wpływ na funkcjonowanie organizacji. Do podstawowych składników należą na przykład: bezrobocie, inflacja, model gospodarki, polityka fiskalna, dostęp do surowców i poziom ich cen, koniunktura gospodarcza i system bankowy.

- kulturowy - historia, tradycja czy ogólnie przyjęty w danym społeczeństwie system wartości.

- społeczny - to zależności demograficzne, wzorce dotyczące stylu życia, mobilność społeczeństwa, instytucje społeczne. Czynnik ten zawiera takie składowe jak: preferencje religijne, przyrost demograficzny, starzenie się społeczeństwa lub jego migracje.

- polityczny - w głównym stopniu to panujący ustrój polityczny i jego stabilność oraz zasady i rozmiary interwencjonizmu państwowego.

- prawny - jest nim obowiązujący system prawny, a w szczególności prawodawstwo związane z działalnością gospodarczą.

- technologiczny - aktualny stan wiedzy oraz dostęp do aktualnych technologii, które mogą zostać wykorzystane i użyte w procesach wytwarzania produktów i usług.

- fizyczny - oddziaływanie środowiska naturalnego, w którym istnieje przedsiębiorstwo ze wszystkimi swoimi ograniczeniami i zagrożeniami jak na przykład katastrofy przyrodnicze.

- międzynarodowy - to oddziaływania instytucji międzynarodowych i trendy globalne.

Należy dodać, że wszystkie czynniki makrootoczenia mogą wchodzić w interakcje nie tylko z przedsiębiorstwami, ale również $\mathrm{w}$ relacje między sobą.

Kolejnym elementem otoczenia przedsiębiorstwa jest jego otoczenie konkurencyjne, które można podzielić na następujące składowe:

klienci, konkurenci istniejący i potencjalni, dostawcy, właściciele (akcjonariusze), władze, grupy nacisku, związki zawodowe. 
Pomiędzy wszystkimi elementami dochodzi lub może dochodzić do interakcji, jak również każdy $\mathrm{z}$ elementów otoczenia danego przedsiębiorstwa może być lub jest elementem otoczenia innych przedsiębiorstw. Posługując się pojęciem systemu możemy stwierdzić, że mamy tu do czynienia $\mathrm{z}$ systemem złożonym, którym jest gospodarka globalna $\mathrm{z}$ globalnym otoczeniem, w którym zanurzona jest ogromna liczba podsystemów, z których najmniejszym jest rozpatrywane przedsiębiorstwo ze swoim otoczeniem.

\section{Relacje pomiędzy przedsiębiorstwem a otoczeniem}

Na przedsiębiorstwo, jako system otwarty oddziałują elementy otoczenia poprzez jego czynniki wejścia, czyli zasoby oraz czynniki wyjścia, czyli produkty i usługi. Ponieważ każde zasoby są ograniczone, a czynniki wyjścia są przyswajalne przez otoczenie w ograniczonej ilości, to system ten jest systemem zależnym. Sytuację tą pokazuje rysunek 2.
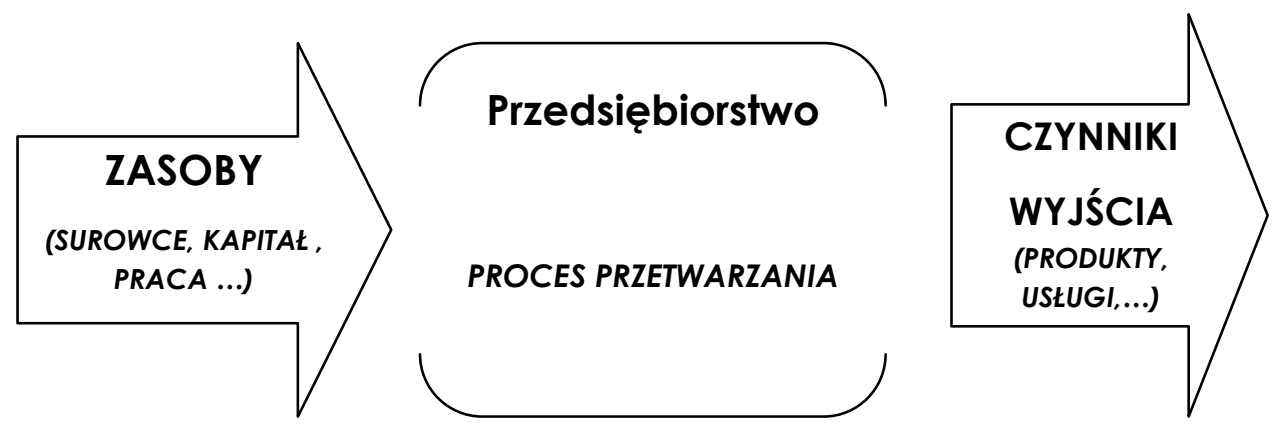

Rys. 2. Przedsiębiorstwo, jako system otwarty, zależny od otoczenia.

Oznacza to jednoznacznie, że otoczenie „rządzi” przedsiębiorstwem, a ono może jedynie szukać strategii, której realizacja będzie tą zależność minimalizować. Ważne jest to, aby zidentyfikować te zasoby, które są istotne dla funkcjonowania przedsiębiorstwa oraz dokładnie rozpoznać niedobory tych zasobów w jego otoczeniu. 
Kolejny krok to poszukiwanie możliwości uzależnienia otoczenia od czynników wyjścia przedsiębiorstwa oraz zabezpieczenie się przed niedoborami zasobów, na przykład przez odpowiednie umowy.

Ponieważ każde przedsiębiorstwo oddziałuje na inne przedsiębiorstwa, to należy starać się, aby jej czynniki wyjścia stanowiły dla innych zasoby istotne oraz próbować tak wpływać na swoje otoczenie, aby stały się one zasobami niedoborów. Przykładem może być produkcja bardzo wyspecjalizowanych półproduktów, które z jednej strony są poszukiwane na rynku, $\mathrm{z}$ drugiej, ich proces produkcji wymaga wysokich nakładów inwestycyjnych. Innym przykładem jest wydobycie surowców naturalnych, które są ważne dla rynku, a których zasoby są mocno ograniczone lub ich wydobycie jest skomplikowane technologicznie.

W teorii nauk o zarządzaniu spotkać można również inne przedstawienia relacji pomiędzy otoczeniem i przedsiębiorstwem.

W teorii instytucjonalnej stawia się przed przedsiębiorstwem dwa podstawowe wymagania: technologiczno-ekonomiczne i społeczne, co oznacza, że otoczenie wymusza na przedsiębiorstwach stosowanie odpowiednich technologii lub odgrywanie określonej roli społecznej. Opisywane jest też pojęcie legitymizacji społecznej jako kolejnego zasobu wejściowego, co oznacza, że przedsiębiorstwo jest uzależnione od akceptacji społecznej. Wszystkie te teorie są zgodne, że przedsiębiorstwo jest zależne od swego otoczenia. Różnice polegają jedynie na perspektywie, z której te relacje są ocenione (analizowane) lub na wyróżnieniu niektórych czynników jako bardziej istotnych lub wprowadzeniu nowych. Inną ważną różnicą jest wyznaczenie wpływu przedsiębiorstwa na otoczenie. Jedynie w pierwszej $\mathrm{z}$ przedstawionych teorii, czyli zależności od zasobów, przedsiębiorstwo jest postrzegane jako aktywny uczestnik mogący zmieniać otoczenie, w innych jest od otoczenia całkowicie uzależnione.

\section{Wpływ otoczenia na proces decyzyjny wyboru technologii}

Ponieważ otoczenie ma wpływ na procesy zachodzące w przedsiębiorstwie, to ma ono również wpływ na decyzje dotyczące wyboru stosowanych technologii. Przez technologie należy rozumieć główne procesy technologiczne wytwarzania produktów i usług przez przedsiębiorstwo oraz procesy przetwarzania surowców. Ważne jest to, aby ustalić, które $\mathrm{z}$ oddziaływań elementów otoczenia są istotnymi oddziaływaniami, decydującymi o wyborze technologii, co umożliwia wybór najkorzystniejszej dla przedsiębiorstwa strategii. 
W każdym sektorze inne oddziaływania elementów otoczenia mają istotne znaczenie dla procesów technologicznych. Również wielkość przedsiębiorstwa, jego położenie geograficzne, dostęp do surowców, wielkość konkurencji odgrywają ważną rolę w wyborze optymalnego procesu technologicznego.

\section{Model procesu decyzyjnego wyboru technologii w przedsiębiorstwie, w warunkach zmiennego oddziaływania otoczenia}

W otoczeniu, które jest zmienne w czasie, wybór technologii jest zależny od kolejnych stanów poszczególnych jego elementów. Poniżej przedstawiono model procesu decyzyjnego wyboru technologii, uzależniony od zmian otoczenia przedsiębiorstwa.

Przez model procesu decyzyjnego rozumie się trójkę uporządkowaną postaci (1):

$$
\left\langle E, A, Z_{E A}\right\rangle
$$

gdzie:

$\mathbf{E}$ jest skończonym zbiorem stanów elementów otoczenia; dla każdej chwili $t \in T$ stan elementów otoczenia jest wektorem $e_{t}=\left\langle e_{1}^{t}, \ldots, e_{n}^{t}\right\rangle$; gdzie $e_{k}^{t}$ oznacza stan $k$-tego elementu otoczenia w chwili $t$.

A jest skończonym zbiorem akcji możliwych do zastosowania do przedsiębiorstwa $\mathrm{W}$ chwili jego znalezienia się $\mathrm{w}$ konkretnym stanie otoczenia $\mathrm{w}$ określonej chwili czasowej; dla każdego stanu $e_{t} \in E, t \in T$ może zostać zastosowana akcja $a_{t}=\left\langle a_{1}^{t}, \ldots, a_{n}^{t}\right\rangle$, przy czym zakłada się, że każde $a_{k}^{t}$ jest wartością ze zbioru $\{0,1\}$. Wartość zero oznacza brak wpływu $k$-tego elementu otoczenia na działanie przedsiębiorstwa, a wartość jeden oznacza, że taki wpływ istnieje.

$\mathbf{Z}_{\mathbf{E A}}$ jest zbiorem funkcji dochodów postaci (2):

$z_{e_{t}}^{a_{t}}: T \rightarrow R$ 
realizowanych $\mathrm{w}$ czasie pozostawania przedsiębiorstwa $\mathrm{W}$ stanie $e_{t} \in E$ przy zastosowaniu akcji $a_{t} \in A$. O funkcjach ze zbioru $\mathrm{Z}_{\mathrm{EA}}$ zakłada się, że są ciagłe i ograniczone.

Omawiany model jest modelem stochastycznym, zmiennym i ciąłym w czasie oraz dyskretnym $\mathrm{w}$ stanie. Oznacza to, że zawiera przynajmniej niektóre zmienne opisowe, które są zmiennymi losowymi, że zdarzenia mogą występować $\mathrm{w}$ dowolnej chwili $\mathrm{t} \geq 0$, a nie jako wielokrotność ustalonej jednostki czasu, oraz że zbiór stanów systemu jest co najwyżej przeliczalny (właściwie w każdej konkretnej aplikacji będzie on skończony).

Przez model decyzyjny rozumiemy model o takiej własności, że w chwili znalezienia się przedsiębiorstwa w konkretnym stanie otoczenia, mogą być stosowane różne akcje, mające wpływ na koszty i dochody przedsiębiorstwa.

Realizacją procesu decyzyjnego, w modelu, dla pojedynczego przedsiębiorstwa, jest ciąg (3):

$e_{0}, a_{0}, e_{1}, a_{1}, e_{2}, a_{2}, \ldots$

gdzie $e_{j}$ określa stan elementów otoczenia, w którym znalazło się przedsiębiorstwo zaś $a_{j}$ określa podjętą akcję dotyczącą przedsiębiorstwa.

Jeśli chwile, w których następują zmiany stanów oznaczymy symbolami $t_{0}, t_{1}, \ldots$, zaś czas pozostawania $\mathrm{w}$ stanach symbolami $\tau_{0}, \tau_{1}, \ldots$, to zachodzi związek (4):

$\tau_{k}=t_{k+1}-t_{k}$.

W czasie znajdowania się przedsiębiorstwa od chwili $t_{k}$ do chwili $t_{k+1} \mathrm{~W}$ stanie $e_{t_{k}} \in E$ i przy założeniu, że w stosunku do tego obiektu została zastosowana akcja $a_{t_{k}} \in A$, to uzyskiwane dochody można opisać funkcją $z_{e_{t_{k}}}^{a_{t_{k}}}(t)$. Dochody uzyskiwane w czasie $\tau_{k}$ tj. od chwili $t_{k}$ do chwili $t_{k+1}$ można opisać zależnością (5): 
$W_{i}^{t_{k}}\left(\tau_{k}\right)=\int_{t_{k}}^{t_{k+1}} z_{e_{t_{k}}}^{a_{t_{k}}}(t) d t$

Wartością średnią (na jednostkę czasu) dochodu uzyskiwanego w czasie od chwili $t_{k}$ do chwili $t_{k+1}$ jest więc (6):

$$
\frac{W_{i}^{t_{k}}\left(\tau_{k}\right)}{\tau_{k}}=\frac{1}{\tau_{k}} \int_{t_{k}}^{t_{k+1}} z_{e_{t k}}^{a_{t_{k}}}(t) d t
$$

Łączna wartość dochodu w okresie kolejnych $n$ zmian stanów (równa polu powierzchni ograniczonej wykresami funkcji dochodów) wyraża się zależnością (7):

$$
D\left(t_{0}, t_{n}\right)=\sum_{k=0}^{n} \int_{t_{k}}^{t_{k+1}} z_{e_{t k}}^{a_{t_{k}}}(t) d t
$$

gdzie $e_{t_{k}}$ oznacza stan otoczenia, w którym znalazło się przedsiębiorstwo w chwili $t_{k}$, zaś $a_{t_{k}}$ jest akcją zastosowaną w chwili znalezienia się systemu W stanie $e_{t_{k}}$.

\section{Podsumowanie}

Opisany model może zostać zaimplementowany do optymalizacji procesów decyzyjnych wyboru technologii w przedsiębiorstwach przetwórczych.

W praktyce dla wybranego sektora należy wyznaczyć oddziaływania elementów otoczenia, istotnych dla wyboru technologii w danym sektorze. Identyfikacja zmian stanów elementów otoczenia może być pomocna do prognozowania ich przyszłych stanów. Jest to bardzo istotne, ponieważ decyzje o wyborze technologii należy podjąć na podstawie tej prognozy, tak, aby wyprzedzały one decyzje konkurencji z uwzględnieniem przyszłych potrzeb rynkowych.

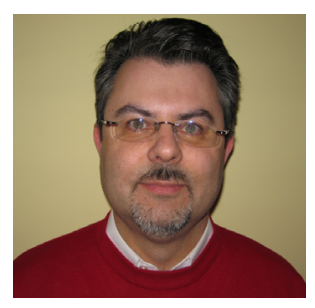

MSc Grzegorz Hoppe, The President Of The Board Remondis Bydgoszcz Ltd.. The company sees about the complex waste management. The candidate for a doctor's degree of Economic Academy in Poznań 